\title{
Party Elites in the 2008 Presidential Nomination Campaigns
}

\author{
Wayne P. Steger
}

Recent studies find that candidate endorsements by party elites play significant role in presidential nomination campaigns. This study analyzes patterns of endorsements by elite office holders to address questions of when and why elites converge on a preferred candidate. The interaction of candidate-, campaign-, and party-centric factors affect the extent to which party elites coalesce around a single front-runner prior to the Iowa caucus. Elite officeholders tend to refrain from preIowa endorsements when there is uncertainty about which candidate will emerge as the front-runner. Elite officeholders are more likely to endorse candidates located near the ideological center of their political party. Elite Republican officeholders appear to have refrained from making an early endorsement in 2007 compared to early nomination campaigns because the Republican nomination campaign has been highly competitive without a clear front runner and none of the candidates are near the ideological center of the party.

The 2008 presidential nomination campaigns offer a historic opportunity to study presidential nominations. This is the first open nomination in the post-1970s reform era in which both parties have an early favorite as a candidate in the race. Early favorites usually win the presidential nomination of their political party if they run, which is one reason polls have been given so much attention by the press and scholars alike (e.g., Keech and Matthews 1976; Adkins and Dowdle 2004; Mayer 1996, 2008). The presence of the early favorite affects the behavior of party elites, who tend to back established candidates who attract strong support in polls (Steger 2008a). A major difference between Republican and Democratic nominations since 1970 has been the tendency not to enter the race by Democratic early favorites (e.g., Ted Kennedy for 1972 and 1976; Mario Cuomo for 1992; and Al Gore for 2004) (Dowdle, Adkins, and Steger 2008). In previous nominations, Democratic elites have been less unified in their support of presidential candidates than have their Republican counter-parts. This study looks at why party elites back the candidates that they do. Do early favorites necessarily gain the support of party elites? Further, when an elite-backed candidate prevails, is it because elites facilitate that candidate's nomination, or does that candidate win for the reasons that led elites to endorse him or her in the first place? The 2008 race and candidate pool provide cases to assess why party elites endorse certain presidential nomination candidates and not others, while holding constant conditions that vary across election cycles.

WAYNE P. STEGER is an associate professor of political science at DePaul University.

The American Review of Politics, Vol. 28, Winter, 2007-2008: 293-318

(C)2007 The American Review of Politics 
Understanding the role of elites in presidential nominations provides insights into normative questions of democracy and power in the American electoral system. If electoral power derives, in part, from having meaningful choices among candidates (Schumpeter 1942, 281-83), the voters' power to choose may be little more than a plebiscitary vote of confidence (or no confidence) of the choices mediated by party elites (Held 1987, 154-166). How much influence do party elites have in shaping the choices available to the rank-and-file party identifiers (and independent leaners) who vote in the caucuses and primaries that select delegates who nominate candidates at the national party conventions? Further, the presidential nominees are a major factor in defining the ideological direction of a political party (Herrera 1995), the main selectors of issues and policies for their party's general election campaign (Petrocik 1996), and they form the set of candidates from which general election voters will choose. How much and under what conditions party insiders influence the selection of the nominee speaks directly to the strength of the political parties as autonomous, meaningful institutions in American politics. If presidential nominations are essentially candidate-centered and mass media affairs, then the power and roles of political parties have diminished with respect to the selection of the most powerful position in the political parties themselves and American government more generally.

\section{Party Elites, the Invisible Primary, and Presidential Nomination Campaigns}

After the reforms of the early 1970 s, political scientists generally came to discount the role and influence of political party elites in presidential nomination campaigns (PNCs). The conventional view was that the adoption of binding caucuses and primaries in the early 1970s shifted power over the selection of the nominee from party and officeholders to party activists and identifiers (e.g., Ranney 1975; Kirkpatrick 1976; Ceaser 1979; Polsby 1983). Though Democratic Party elites gained "super-delegate" status at their national convention beginning in 1984, their votes have not been decisive in determining the nominee, with the possible exception of 1984 (Norrander 2000). The general view is that endorsements probably do not carry much weight with most rank-and-file partisans (e.g., Broder 1999). PNCs are lowinformation environments in which most people are relatively inattentive and uninformed about the candidates and their policies (e.g., Gopoian 1982; Keeter and Zukin 1983; Geer 1989; Kenney 1993), much less who is backing them. Public inattentiveness and ignorance limit the impact that endorsements can have on caucus and primary voters' choices.

Yet recent studies have found that candidate endorsements, taken in the aggregate, are important predictors of outcomes in presidential nomination 
campaigns. Endorsements affect mass partisan preferences for candidates before (Dowdle, Adkins, and Steger 2008) and during the early caucuses and primaries (Jamieson et al. 2000). Cohen et al. (2003, 2008a) find that candidate endorsements by party and elected officials are at least as strong of predictors of the candidates' share of the delegate count as are national polls, campaign funds, or media coverage. Steger (2007a, 2008c) similarly finds that candidate endorsements by elite officeholders (presidents, vice presidents, governors, senators, and representatives) are strong predictors of the aggregate and contested primary vote for both political parties, controlling for candidates' poll position, cash reserves, and ideological position. Thus endorsements by party elites, defined broadly or narrowly, are a strong indicator of candidates' chances of winning presidential nominations between 1980 and 2004.

Cohen, Karol, Noel, and Zaller (hereafter CKNZ) (2003, 2008a, 2008b) argue that party and officeholders play a significant role in shaping the race before the primaries. Following the turbulence of the post-reform era of the 1970 s, the nominating process settled into a pattern in which a front-runner emerges in the invisible primary and parlays this success into success in the primaries (see also Mayer 1996a). According to CKNZ, the invisible primary is the mechanism by which political party insiders identify and unite behind a candidate who can win the nomination and fall election. Faced with the need to compete in fifty state primaries and caucuses, presidential candidates have no choice but to enlist help (CKNZ 2008a, 8). Candidates meet, woo, and try to gain the support of leading members of their party (officeholders, party officials, interest group leaders, citizen activists, and anyone who works regularly for the party) (CKNZ 2008a, 2). At the same time, party insiders try to identify which candidates will maintain party orthodoxy and will be strong competitors in the general election. Faced with multiple candidates seeking support, party insiders have a lot of choice, but they must coordinate and unify if they are going to affect the outcome (CKNZ 2008a, 8). Party elites communicate with each other informally as well as through the media as to which candidate will advance party goals and principles. Party insiders rally around a candidate broadly acceptable to party constituencies in order to strengthen that candidate's presidential nomination campaign. Steger (2008a) argues that party elite influence on the nomination depends on the degree to which party elites coalesce in support of a candidate and help them gain resources, media coverage and organizational support before the primaries (see below).

CKNZ and Steger differ in two respects. First, CKNZ view the process as a party-centric affair while Steger views it more as an interaction between candidate-centric factors in a party context. Second, they differ in the relative weight that ideology versus viability and electability have on endorse- 
ment decisions. CKNZ (2008a, 2008b) portray party insiders as cooperating to advance party themes by identifying and supporting a candidate who will maintain party orthodoxy and who can win in the general election. Steger argues that elite party office holders' proximate concern is supporting a candidate who can win the nomination and be a strong competitor in the general election, and secondarily, of supporting party orthodoxy. Ideological appeal and a candidate's chances of winning the nomination (viability) and the general election (electability) are inherently linked. Being a strong competitor in the nominating and general elections requires broad appeal among party constituencies because the various segments of the party base must be on board if the party is going to win the general election. Viability and electability seem to be prioritized by more officeholders because officeholders are more likely to endorse a less preferred but acceptable candidate who can win, than they are to endorse an ideologically preferred candidate who cannot win (Steger 2008b).

Though some officeholders appear to endorse presidential candidates for ideological reasons, most do not. U.S. Senators and Representatives typically endorse a presidential candidate other than the one ideologically closest to themselves (Steger 2007b). Indeed, the most liberal and moderate Democratic and the most moderate and conservative Republican candidates receive few endorsements, even though there are numerous officeholders with similar ideological positions. These candidates are less likely to unify the party and win in the general election.

This does not mean that ideology is irrelevant. Officeholders rarely endorse a candidate who is ideologically unacceptable. Rather, there usually are several ideologically acceptable candidates and officeholders tend to support a candidate who is ideologically acceptable to a broad range of party members. Specifically, elite party office holders most often support a viable and electable candidate from among those candidates near the ideological center of the party. Party insiders realize that candidates near the ideological center of the party will appeal to more of the party's diverse constituencies than would a candidate further from the center.

\section{The Impact of Party Elite Support in Presidential Nomination Campaigns}

The invisible primary provides opportunities for party elites to influence presidential nomination campaigns before the caucuses and primaries (Cohen et al. 2008a; Steger 2008a). First, the pre-primary competition for resources provides an opportunity for party insider to influence the competitive balance among candidates. Second, the pre-primary period provides an opportunity for party insiders to shape public perceptions of the candidates 
(e.g., Popper 1991, 134, 160). Importantly, the impact of party elites on the nomination is contingent on their unity in their support of a nomination candidate. The ability of party elites to tip the competitive balance among candidates and mold public perceptions diminishes as they divide their support among the candidates.

Beginning in the 1950s, presidential candidates have sought nominations by raising funds, building their own campaign organizations, and communicating their own issue priorities and campaign messages (e.g., Reiter 1985). The rising costs of candidate-centered campaigns combined with front-loading of primary schedule have produced a major competitive gap between candidates who can obtain resources, exposure, and support before the primaries and those who cannot (Adkins and Dowdle 2002). Candidates' relative abilities to compete during the primaries are largely determined by the pre-primary competition for resources and exposure; and the playing field is effectively tilted in favor of those obtaining money, media exposure, and partisan support (Steger, Adkins, and Dowdle 2004). Party elites can influence nominations first by supporting candidates' efforts to build organizational and fundraising networks.

Party elites facilitate candidates' efforts to build strong personal networks of contributors and volunteers from the overlapping organizations and networks that form the modern political parties (e.g., Merrion 1995; Gimpel 1998). Candidates use endorsements in their fundraising appeals (Bimber and Davis 2003). Party elites frequently serve as headliners at fundraising events with or on behalf of presidential candidates (e.g., Novak 2006). Endorsements also limit the resources available to other candidates (e.g., Embrey 1995). Endorsements are used in campaign communications as candidates announce them at rallies and press conferences and display them in advertisements and web pages (Bimber and Davis 2003; Williams et al. 2008). Party elites also may be deployed as proxies in attacks on rivals, which is effective because party and officeholders are "credible" sources of criticism and may insulate the candidate from charges of negative campaigning (Garramone 1985). While some endorsements are more valuable than others, in terms of active support for the campaign, the aggregate pattern of endorsements provides an approximate indication of insider support for candidates' campaign efforts. Candidates with more elite support are going to have an easier task raising money and building their campaign organizations than candidates lacking such support.

Nomination campaigns exhibit varying degrees of uncertainty about how candidates will play with voters in the caucuses and primaries. Under conditions of uncertainty, elites can influence media coverage and commentary of the campaign. In an uncertain environment, journalists, editors, and producers look for cues about what to cover and how to cover it (Shaw and 
Sparrow 1999). Journalists pay close attention to polls and quarterly financial reports to figure out which candidates are leading, lagging, rising, and falling. But national news reports also frequently incorporate subjective elite judgments that are not reflected in objective indicators of the horse race (e.g., Cillizza 2006). This effect can be seen in the coverage of candidates who led in national polls prior to the primaries, but who were not treated like front-runners by the media (witness George Wallace in 1975; Jesse Jackson in late 1987; and Joe Lieberman in 2003). Party elites contribute to the perceptions conveyed to the public through their contact with reporters and through news reports of party elite support for candidates.

While the general public is inattentive to the presidential nomination campaign; party activists, campaign contributors, and organizations aligned with the parties are more likely to be exposed to this information. This matters because these attentive publics, along with the news media, provide candidates with the money and exposure needed to compete for the support of larger numbers of primary voters across the country. Endorsements also affect voting in later primaries indirectly through their effects on voters in early caucuses and primaries. Unlike the public at large, prospective voters in early caucus and primary states are exposed to a high volume of information provided by the news media and campaign advertisements. A study by the Annenberg Public Policy Center shows that most voters in the early caucuses and primaries were exposed to endorsement information during the 2000 PNCs (Jamieson et al. 2000). Further, the study found that endorsements did influence some votes in these elections, especially when endorsements are communicated to the public in campaign ads. This suggests that endorsements have the greatest potential effect in the early contested states in which candidates invest heavily in time and money. This matters because the early caucus and primary outcomes affect the vote in later states (e.g., Bartels 1988). Thus endorsements indirectly affect the primary vote by influencing candidates' relative abilities to compete in the primaries and through the vote in the early caucuses and primaries.

Importantly, as Cohen (2008a) and Steger (2008a) both argue, party elites influence in the nomination campaign to the extent they unify or coalesce behind a candidate. Party elites dilute their impact when they refrain from making endorsements or when they divide their support for candidates. As elites divide their support for candidates, they send a mixed signal to each other and to their attentive partisan publics. Candidates who gain large numbers of endorsements are signaled to be ideologically acceptable and viable because they are receiving support from across the spectrum of the party's elite membership. People tend to accept opinion leadership from credible sources (Zaller 1992). An individual endorser may not be a credible source for a given partisan, so an individual endorsement may or 
may not resonate with an individual party activist or contributor. When elites divide their support for presidential candidates, attentive publics, we can expect attentive party audiences to divide along lines similar to those among elites, giving credence to endorsements of preferred politicians while discounting those of less preferred or unfamiliar politicians. As more elite party officials endorse a candidate, the odds improve that a given party activist or identifier will find a credible endorser. When most elites coalesce behind a given candidate, the signal is unified as to which candidate is desirable, viable and electable.

Candidates who gain endorsements from only a segment of the party elite are signaled to have more limited appeal-usually defined by geography, ideology or race. Jesse Jackson, for example, received 17 endorsements prior to the 1988 Iowa Caucuses. All but one of these endorsements came from members of the Black Congressional Caucus (BCC). Jackson failed to gain the endorsements of a majority of the BCC. Jackson's inability to broaden his support among party elites foretold his inability to expand his support during the 1988 primaries. Similarly, candidates whose endorsements are limited to their home state politicians are signaled to have limited appeal. Richard Lugar's bid for 1996 Republican nomination, for example, failed to gain support from party elites beyond Indiana; which roughly coincided with the geographic limits of Lugar's fund-raising base and his share of support in national polls.

Candidate endorsements by elite party officials thus both indicate a candidates appeal and strength as well as contribute to a candidate's strength. Elite endorsements tell us about the range of appeal that a candidate can be expected to have in the caucuses and primaries. Candidates who attract large numbers of endorsements from elite party officials probably have the personal and political characteristics to appeal to a wide range of the party's mass membership, and therefore will attract support in the caucuses and primaries and motivate partisans in the general election. Endorsements before the caucuses and primaries also affect nomination outcomes by influencing candidates' relative abilities to compete for the support of prospective primary voters, and by influencing the information conveyed through the media as journalists gauge candidates' support. Party elites can influence the nomination outcome to the extent that they coalesce and endorse candidates early - when the media, activists, and contributors need information about who they should pay attention to. When more party elites support a candidate, they collectively signal that the candidate is more desirable and viable. In sum, a candidate who receives the most endorsements probably has the characteristics that make her likely to win, and gains the means to do so in the caucuses and primaries. 


\section{Early Favorites, Partisan Differences, and Endorsement Behavior}

Steger (2008a) hypothesized that endorsement patterns differ in nomination races with and without the early favorite as a candidate. First, the decision of the early favorite can affect other candidates' entry decisions (e.g., Butler 2004). When the early favorite opts not to run (as happened in the Democratic nominations of 1972, 1976, 1992, and 2004), the race becomes more competitive with more evenly matched candidates going into the primaries. Early favorites tend to gain the resources, exposure, and support needed to run strong campaigns. Without an early favorite in the race, resources tend to distribute more widely among the candidates. Early favorites also tend to do well because they are relatively well known and have established images, which give them two advantages. One, they need fewer resources to establish themselves among voters so they can conserve resources for the primary season. Two, their support tends to be stable compared to lesser known candidates (e.g., Adkins and Dowdle 2004). In nomination campaigns without the early front-runner as a candidate, national polls exhibit considerable instability as support shifts from candidate to candidate during the pre-primary period (Dowdle, Adkins, and Steger 2008).

From the perspective of party elite officeholders, the presence of the early favorite in the race reduces uncertainty. The early favorite in polls will be a viable candidate. An early favorite is widely known and has an established image, which enables elites to estimate whether that candidate will play well with their constituents. Elites generally know what they are getting with a candidate sufficiently well known to lead in national polls two or three years before a presidential election. Without an early favorite in the race, there is greater uncertainty about which candidates will be viable contenders for the nomination and how well each candidate will play with constituents in the general election. In this more uncertain environment, party elites have less incentive to endorse early.

In the post-reform era, the patterns of candidate entry have often differed for the two parties in open presidential nominations (e.g., Berggren 2007). Republicans more often have had a clear front-runner to rally around early in the campaign (Butler 2004), whereas Democratic nominations have tended to lack a clear front runner prior to the primaries (Adkins and Dowdle 2004). The Democrat leading in national Gallup polls two years before the election did not run in the open nominations of 1972, 1976, 1992, and 2004. In addition, the early favorite going into the 1988 Democratic nomination, Gary Hart, withdrew in early 1987 after exposure of marital infidelities. All of the open Republican races (1980, 1988, 1996, and 2000) included the early favorite as a candidate. Steger found that Republican elites more often coalesced around nomination candidates than did Democratic elites, but the 
key factor is the competitiveness of the nomination race. There is more uncertainty about which of the candidates in the race will emerge as a frontrunner when the early favorite sits out the race (e.g., Dionne 1987). The uncertainty that characterizes most post-reform, open Democratic nominations likely affected the propensity of Democratic elites to endorse candidates prior to the caucuses and primaries (Steger 2008a). Until 2008, Republican elites have not faced the same degree of uncertainty about their candidates. The impact of the early favorite on endorsements should be more apparent in 2008 because both parties have their early favorite as a candidate in the race-Hillary Clinton for Democrats and Rudolph Giuliani for Republicans.

\section{Data and Measurement}

Data on candidate endorsements by elite office holders (Presidents, Vice Presidents, Governors, Senators, and U.S. Representatives) was obtained from Eric Appleman's Democracy in Action website sponsored by George Washington University. These data are available at http://www.gwu.edu/ action/2008/cands08/endorse08el.html (data accessed at various dates in 2007 and January 2008). To ensure that all endorsements by governors, senators, and representatives were included in the dataset, the Lexis-Nexis search was reiterated for the names of each official not previously identified as endorsing a candidate. We also cross-referenced our lists of endorsements with those reported on candidate websites for 2008 . These additional searches yielded a couple of additional endorsements, increasing our confidence that the measures are reliable and valid for the office-holders in the analysis. The measure used is the cumulative sum of endorsements aggregated to the quarterly level and until the Iowa Caucuses for the election year.

Estimates of candidate ideology were derived from the DW1 and DW2 common space scores for all members of Congress in the two years leading up to an election (see Poole and Rosenthal 1997; http://voteview.com). According to Poole and Rosenthal, both axes are equally salient. The DW1 axis can be interpreted as candidate positions on government intervention in the economy or an economic liberal-conservative dimension (Poole and Rosenthal 1997). The DW2 (vertical) axis is less clearly defined, but has related to cleavages on issues that have shifted over time from slavery to the debate over silver versus gold currency to civil rights to social or cultural issues for the most recent congresses. According to Poole, Rosenthal, and McCarty (1997), the realignment of Southern Democrats to the Republican Party has largely reduced the significance of the second dimension (see also Poole and Rosenthal 2001). The data 
generally are stable for individual legislators since scores are based on the entire history of a legislator's roll call votes.

The actual DW scores are used for presidential candidates who were members of Congress at the time of their candidacy (Democrats Joe Biden, Hillary Clinton, Christopher Dodd, Dennis Kucinich, and Barak Obama; and Republicans Sam Brownback, Duncan Hunter, John McCain, and Ron Paul). Since DW nominate scores are generally stable over time, the projection into the future is a reasonably valid and reliable measure for former representatives and senators. Thus the DW common space scores are used for former U.S. representatives and senators from their most recent term of service in the House or the Senate (former Senators John Edwards and Mike Gravel and former Representative Bill Richardson on the Democratic side and Fred Thompson on the Republican side). Governors likely face similar electoral constraints as a senator of their political party (Kenny and Lotfinia 2005, 446). For candidates who are or were governors, the estimate is the average of the common space scores of the representatives and senators of their party's congressional delegation (Governors Mitt Romney, Mike Huckabee, and Tommy Thompson on the Republican side). For Rudolph Giuliani, holding mayoral office, I used the average DW scores of Republican officeholders from New York City and Long Island. These data allow for mapping of candidates onto the ideological space of their party's elite officeholders (excluding governors).

\section{Results and Discussion}

\section{Propensity to Endorse, a Statement About the Strength of the Candidates Running}

Steger (2008a) found that elite Democratic officeholders generally have taken a "wait-and-see" approach, often waiting to endorse candidates who emerge during the primaries. Proportionately fewer Democratic governors, senators and representatives endorse a candidate prior to the Iowa caucuses compared to their Republican counterparts in open nominations between 1984 and 2004 (reproduced in Table 1). Democrats endorsing a candidate also did so later than their Republican counterparts. By comparison, more elite Republican officeholders endorsed presidential candidates and did so earlier than Democratic officeholders. News accounts of Republican presidential nominations since 1980 have been, in part, narratives about party elites coalescing around candidates early in the campaign. George W. Bush is the strongest example of this early rally. While the Republican elite rally of 1999 was more extensive than in other nominations, the story line parallels what happened in 1980, 1988, and 1996 (e.g., Embrey 1995; Merrion 
1995). As a result, Republcian officeholders usually send a stronger signal to their party's activists, contributors, and aligned groups compared to the Demcrats.

Steger (2008a, 2008b) attributed these differences to a number of partyand candidate-centric differences between the nomination campaigns of the two political parties. In particular, Steger argued that party elites were more likely to make an endorsement, do so earlier, and unify to a greater extent when the early favorite was a candidate in the race. The early favorite is an obvious choice for party insiders. In nomination races without an early favorite, party elites tend to be more hesitant about making endorsements. The extreme case occurred in 1991 when early favorite New York Governor Mario Cuomo did not confirm or deny his candidacy until October of 1991. Cuomo's equivocation effectively froze the race until he unequivocally announced that he would not run (Winneker 1991). Without an early favorite in the race, there is considerable uncertainty about the viability and electability of candidates in the race, which may lead party elites to refrain from making early endorsements.

Note that the presence of an early favorite in the race usually, but not always, reduces uncertainty about which candidates will be strong contenders. It is possible that an early favorite in the polls has vulnerabilities that limit their chances of winning the nomination or general election. Party elites are more likely than the mass public to know about such vulnerabilities and take these limitations into account when deciding who to support. The 1988 Democratic campaign illustrates this tendency. Although Gary Hart led in polls in 1985, 1986, and early 1987, Democratic elites did not flock to Hart's candidacy before he dropped out of the race. Hart's example demonstrates that the early favorite in polls may not be supported by party elites. This is one reason why gauging elite support for a nomination candidate may be a stronger predictor of the primary vote than national Gallup polls (see also Cohen 2008a).

But even taking early polls and candidate-entry patterns into account, Democratic elite officeholders have been less likely to endorse a presidential candidate compared to their Republican counterparts (Table 1). One reason may simply be that the cultures of the two political parties result in differences in elite behavior (e.g., Berggren 2007). A second may be that Democrats with superdelegate status, which now includes all elite officeholders, are supposed to refrain from public endorsements until after the voters have had a chance to speak. The recommendation not to endorse a candidate, however, may be waning. The Democratic National Committee DNC apparently stopped admonishing against early endorsements after the 1992 campaign (Steger 2008a). In any event, more elite Democratic officeholders make endorsements even as the superdelegate status was expanded. 
Table 1. Cumulative Proportion of Governors, Senators, and U.S. Representatives Endorsing a Presidential Candidate Before the Iowa Caucus, by Quarter in Open Nominations, 1984 to 2008

\begin{tabular}{|c|c|c|c|c|c|c|}
\hline Nomination & Endorser & Q1 & Q2 & Q3 & Q4 & Jan \\
\hline \multirow[t]{3}{*}{1984 Dem } & Governor & 5.9 & 8.82 & 29.4 & 38.2 & 41.2 \\
\hline & Senator & 1.9 & 3.7 & 9.3 & 11.1 & 16.7 \\
\hline & U.S. Rep & 2.2 & 12.3 & 15.6 & 16.7 & 43.9 \\
\hline \multirow[t]{3}{*}{1988 Dem } & Governor & 0 & 11.5 & 15.4 & 19.2 & 19.2 \\
\hline & Senator & 1.8 & 9.1 & 10.9 & 12.7 & 14.5 \\
\hline & U.S. Rep & 6.2 & 14.7 & 17.4 & 24.8 & 49.2 \\
\hline \multirow[t]{3}{*}{1992 Dem } & Governor & 0 & 0 & 0 & 14.3 & 52.4 \\
\hline & Senator & 0 & 0 & 1.8 & 16.1 & 30.4 \\
\hline & U.S. Rep & 0 & 0 & 0 & 9.0 & 12.4 \\
\hline \multirow[t]{3}{*}{2000 Dem } & Governor & 0 & 21.1 & 31.6 & 42.1 & 57.9 \\
\hline & Senator & 4.4 & 8.9 & 51.1 & 60.0 & 62.2 \\
\hline & U.S. Rep & 0.9 & 6.6 & 27 & 53.1 & 62.6 \\
\hline \multirow[t]{3}{*}{2004 Dem } & Governor & 4.5 & 9.1 & 9.1 & 13.6 & 13.6 \\
\hline & Senator & 6.3 & 10.4 & 16.7 & 18.8 & 20.8 \\
\hline & U.S. Rep & 12.3 & 37.3 & 45.1 & 63.7 & 69.1 \\
\hline \multirow[t]{3}{*}{2008 Dem } & Governor & 11.1 & 22.2 & 25.9 & 44.4 & \\
\hline & Senator & 15.6 & 20.0 & 26.7 & 28.9 & \\
\hline & U.S. Rep & 29.0 & 37.2 & 44.6 & 55.0 & \\
\hline----- & ---- & -- & --- & --- & --- & --- \\
\hline \multirow[t]{3}{*}{1988 Rep } & Governor & 8.3 & 20.8 & 20.8 & 58.3 & 58.3 \\
\hline & Senator & 2.2 & 8.9 & 11.1 & 17.8 & 31.1 \\
\hline & U.S. Rep & 10.7 & 15.8 & 19.2 & 19.2 & 67.2 \\
\hline \multirow[t]{3}{*}{1996 Rep } & Governor & 13.3 & 20.0 & 33.3 & 76.7 & 83.3 \\
\hline & Senator & 22.6 & 35.8 & 60.4 & 62.3 & 75.5 \\
\hline & U.S. Rep & 10.0 & 30.9 & 57.0 & 60.4 & 62.6 \\
\hline \multirow[t]{3}{*}{2000 Rep } & Governor & 38.7 & 51.6 & 100.0 & 100.0 & 100.0 \\
\hline & Senator & 14.5 & 43.6 & 52.7 & 70.9 & 76.4 \\
\hline & U.S. Rep & 26.5 & 43.0 & 56.5 & 65.5 & 78.0 \\
\hline \multirow[t]{3}{*}{2008 Rep } & Governor & 30.0 & 30.0 & 30.0 & 40.0 & \\
\hline & Senator & 29.8 & 31.9 & 38.3 & 48.9 & \\
\hline & U.S. Rep & 35.5 & 38.6 & 45.2 & 42.8 & \\
\hline
\end{tabular}


A third reason Democratic elites may be more hesitant to endorse presidential candidates is that intra-party divisions make it hard to find a candidate who will appeal to the whole of the party (Mayer 1996b), though intra-party differences have declined since the 1970s (e.g., Poole, Rosenthal, and McCarty 1997).

Another explanation may be that party officeholders are uncertain or ambivalent about their choices. Ambivalence may arise from a lack of policy agreement (a factor that varies with the degree of intra-party unity) as well as electoral considerations. Officeholders may refrain from endorsing candidates who are not going to appeal to their constituents out of concern for their own reelections. Officeholders want someone at the top of the ticket who will help or at least not hurt candidates lower on the ticket in their part of the country (Butler 2004). Officeholders from swing districts and battleground states are in a more precarious electoral position. Such officials may try to avoid public commitments to presidential candidates who may not play well with voters in their districts or states. Officeholders who are at the ideological fringes of their party may refrain from endorsing candidates who are associated with the other end of the spectrum from themselves (i.e., liberal Democrats are unlikely to endorse moderates and vice versa). In both parties, ideological moderates in Congress - those who typically come from swing districts or states, are less likely to endorse presidential candidates (Steger 2007b). More generally, uncertainty about the electoral appeal of candidates may lead officeholders to refrain from making endorsements until they have a better idea about the vote getting power of the candidates. Electoral appeal may be rooted in policy or personal characteristics.

The 2008 race suggests that the race-entry decision of the early favorite (a candidate-centric factor) is less significant than the relative strength of the candidates and their ability to appeal to the full range of the party membership. Endorsement behavior during the invisible primary stage of the 2008 nomination races differs somewhat from the patterns in prior years. The invisible primary began similarly to prior nomination campaigns for both political parties, with proportionately more Republican officeholders endorsing candidates in the first half of 2007 compared to Democratic officeholders. However, by the end of 2007, proportionately more Democratic office holders had endorsed a presidential candidate than had Republican officeholders. In particular, more Democratic governors endorsed a candidate than in any other open nomination since the 1970s. Republican officeholders were less likely to endorse presidential candidates than they had in previous open nomination races.

The differences in endorsement behavior in 2007 compared to prior years suggests that prior endorsement patterns may be less candidate- or party-centric than previously thought, but rather may vary with the competi- 
tiveness of the nomination race. The 2007 Democratic race had a number of strong candidates, with two candidates stronger than the rest during the invisible primary. Senators Clinton and Obama demonstrating strength in fundraising and in the polls compared to other Democratic candidates, with Senator Clinton having a sizeable lead in pre-Iowa national polls. Specifically, Clinton usually received more than 40 percent of respondents compared to the mid-twenty percentile range for Senator Obama in national polls during the invisible primary. The 40 percent mark has been identified by Mayer (2008) and Steger (2008c) as something of a threshold for identification of a strong front-runner. Every candidate with more than 40 percent in national polls by the end of the invisible primary has won the nomination since the McGovern-Fraser reforms. These races have not been very competitive during the primary season, though individual primaries may have been contested and upsets occurring. In campaigns that were competitive late into the primary season (i.e., the Democratic races of 1976, 1988, 1992, and 2004), no candidate held as much as 30 percent in national Gallup polls at the end of the invisible primary. The 2008 Democratic race fits the profile of a less competitive race like those of 1984 and 2000 when a front-runner emerged before the Iowa caucus. Such clarity in identification of the frontrunner has been associated with higher proportions of endorsements in prior nominations in both political parties (Table 1 and Steger 2008a).

By comparison, the 2008 Republican race has been uncommonly competitive-for Republicans, throughout the invisible primary. Though Rudolph Giuliani generally led in national Gallup polls during 2007, neither he nor any other Republican candidate consistently topped 30 percent in national Gallup polls. This suggests that Giuliani is a weak front-runner going into the Iowa caucuses. Moreover, national polls indicated that a series of candidates rose and fell in the polls. Finally, multiple Republican candidates are roughly even in fund-raising (at low levels compared to prior Republican nomination campaigns and compared to Democrats in 2007). The lack of a clear front-runner and volatility in polls during the invisible primary along with no clear fund-raising leader reflect the considerable uncertainty about which Republican candidate would or could attract the support of party activists and identifiers for the nomination and general election. Such uncertainty about the candidates in the race has contributed to the hesitancy of elite office holders in previous (Democratic) nominations (e.g., Steger 2008a, 2008b). The competitiveness of the Republican race and resulting uncertainty likely are major factors constraining elite Republican office-holders' endorsement of their nomination candidates.

Overall, the fact that proportionately fewer Republican officeholders made endorsements compared to Democrats and compared to Republican officeholders in prior years indicates that the 2008 Republican candidate 
field has weaknesses. Elite Republican officeholders are ambivalence or uncertainty about their presidential nomination candidates and are taking a wait-and-see attitude to a much greater degree than they have done in the past. Democratic officeholders are less hesitant to commit to candidates, indicating that they are less ambivalent or uncertain about their presidential nomination candidates.

\section{Party Elite Coalescence}

In open nominations between 1976 and 2004, elite Democratic officeholders tended to scatter their support among the candidates in the race while Republican officeholders coalesced around candidates with greater unity (Steger 2008a). Only in the 2000 nomination race did elite Democratic officeholders unify solidly behind a presidential candidate, when nearly all backed Vice President Al Gore (Steger 2008b). Endorsements by elite officeholders of the two political parties show the opposite pattern for the invisible primary of 2008.

Elite Republican officeholders, making an endorsement, scattered their support among the candidates (Table 2). There is little consensus among elite Republican officeholders as to which candidate should gain the nomination. Instead, the distribution of Republican endorsements is very similar to the distribution of Democratic endorsements in 1988 and 2004 - the most competitive primary seasons since 1980 in either party. Mitt Romney gained the most endorsements, with about a third of the pre-Iowa endorsements made by elite Republican officeholders. Rudolph Giuliani, the leader in

\section{Table 2. Share of Candidate Endorsements by Elite Office Holders by the End of the Invisible Primary, 2008}

\begin{tabular}{lclc}
\hline $\begin{array}{l}\text { Republican } \\
\text { Candidates }\end{array}$ & $\begin{array}{c}\text { Share of } \\
\text { Endorsements }\end{array}$ & $\begin{array}{l}\text { Democratic } \\
\text { Candidates }\end{array}$ & $\begin{array}{c}\text { Share of } \\
\text { Endorsements }\end{array}$ \\
\hline Giuliani & 19.5 & Biden & 1.3 \\
Huckabee & 3.8 & Clinton & 55.6 \\
Hunter & 4.5 & Dodd & 5.9 \\
McCain & 24.8 & Edwards & 10.5 \\
Romney & 33.1 & Obama & 22.9 \\
F. Thompson & 14.3 & Richardson & 4.6 \\
Note: Table shows only candidates remaining in the race by the Iowa Caucus. Democrats Michael \\
Gravel, Dennis Kucinich, and Tom Vilsack and Republicans Tom Tancredo and Tommy Thompon \\
gained no endorsements by elite officeholders during the invisible primary. Republican Sam Brown- \\
back gained one endorsement prior to dropping out of the race.
\end{tabular}


national polls throughout the invisible primary, ranked third with 19.5 percent of elite officeholder endorsements. This suggests that party elites saw limitations to Giuliani's candidacy to a greater extent than mass partisan identifiers. Giuliani's limitations are greatest in red states. Just over 73 percent of Giuliani's endorsements come from elite officeholders in blue states. No other candidate in either party drew so much of their elite support from officeholders in states won by the other political party. Romney, by comparison gained 75 percent of his endorsements from red state Republican politicians. McCain gained endorsements from almost equal proportions of red and blue state Republican politicians.

Endorsements by elite Democratic officeholders are substantially more concentrated. In a reversal of party endorsement patterns in prior nomination campaigns, Democratic officeholders showed more consensus than Republicans in 2007. Hillary Clinton attracted 55.6 percent of the endorsements by elite Democratic officeholders. Since 1980, every candidate who gained more than 50 percent of the endorsements from their party's elite office holders has gone on to win their party's presidential nomination. Aside from Clinton and Obama, most of the other Democratic candidates drew support mainly from their home-state officeholders, suggesting that each of the other Democratic candidates had more limited appeal.

The significance of these patterns is in the signal being sent to attentive audiences - party activists, campaign contributors, aligned interest groups and the media. Republican officeholders in 2007 sent mixed signals to their attentive constituencies as to which candidate is the most preferable, viable, and electable. Democratic officeholders sent a more unified signal that Hillary Clinton is the preferred candidate. Aside from Clinton, only Obama gained a notable share of endorsements other than those made by home state officeholders.

\section{Ideology and Elite Endorsements in 2008}

Figure 1 presents the estimated ideological placements of candidates in two dimensional policy space of the Democratic and Republican congressional delegations using DW1 and DW2 common space scores from 20052006. The DW1 (horizontal) axis can be interpreted as candidate positions on government intervention in the economy or an economic liberalconservative dimension (Poole and Rosenthal 1997). The DW2 (vertical) axis is less clearly defined, but has related to regional divisions with issues that have shifted over time from slavery to the debate over silver versus gold currency to civil rights to social or cultural issues for the most recent congresses. Several observations are worth noting. 
Figure 1. Presidential Candidate Placement in DW1 and DW2 Space

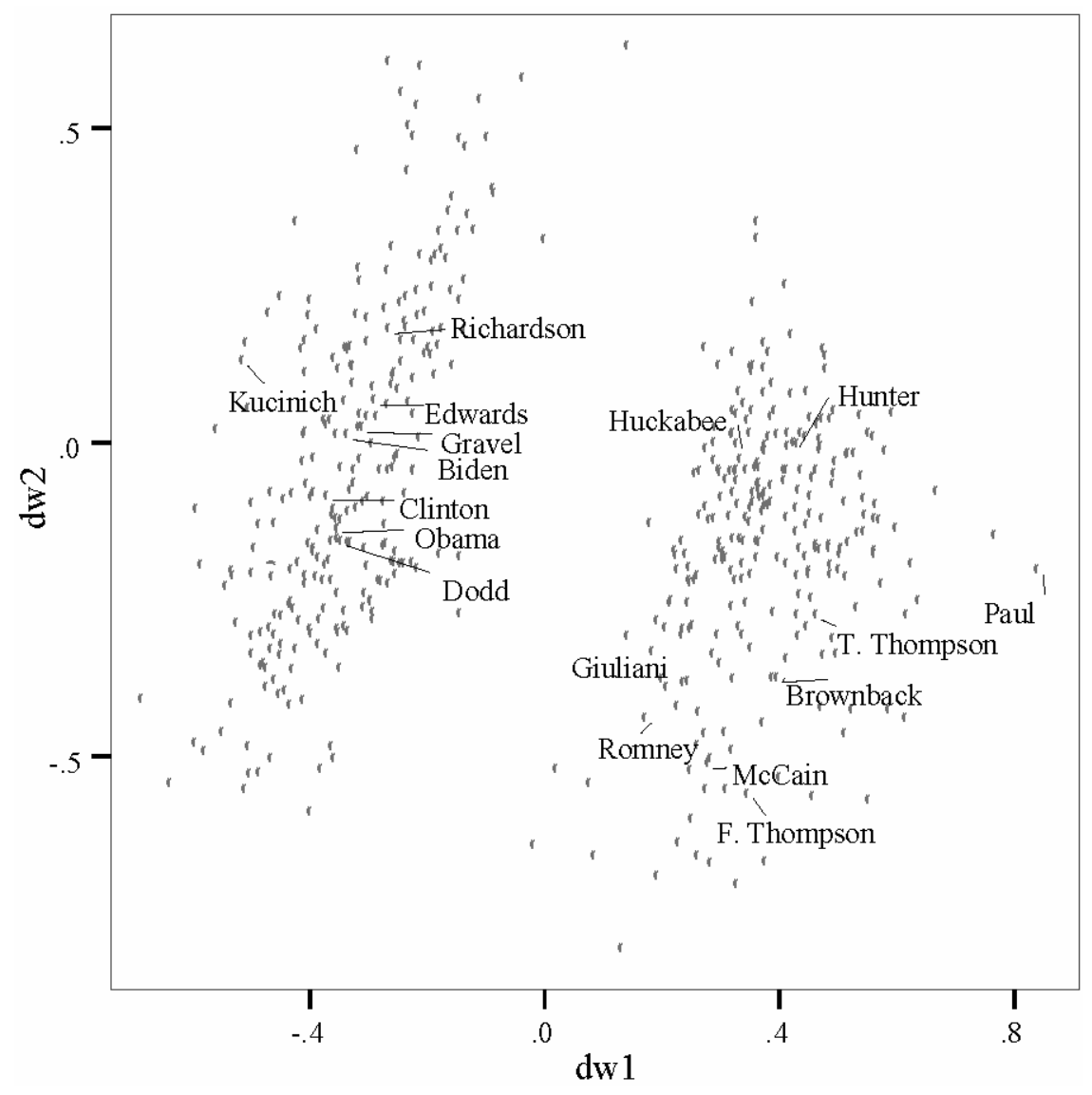

All of the Democratic candidates, except Dennis Kucinich, are centrist Democrats with respect to the DW1 dimension reflecting ideological divisions on economic issues. With the exception of Kucinich, all of the Democratic nomination candidates are ideological centrists with respect to the Democratic congressional delegation on economic issues. The Democratic nomination candidates are more differentiated along the DW2 dimension reflecting social issues for the time period in question. But even on this dimension, the Democratic candidates cluster around the ideological center of the congressional party's ideological space. Importantly, the similarities of the candidates on the ideological dimension means that differences in endorsements almost certainly cannot reflect ideological preferences by endorsers based on this dimension. Recall that Cohen et al. (2008a) argue 
that party insiders endorse candidates who maintain party orthodoxy. When all of the candidates reflect an orthodox party position, then differences in endorsement across candidates cannot be the result of differentiation among candidates on the basis of party orthodoxy or ideological positioning of candidates.

The pattern for Republican candidates is much substantially different. None of the Republican candidates are located near the ideological center of the Republican Party - measured by the ideological space of the Party's congressional contingent. Instead, the candidates range from the moderate Mitt Romney (estimated) to the very conservative Ron Paul-the most ideologically extreme member of Congress in the 109th Congress on the DW1 dimension. The candidates also vary substantially on the DW2 dimension, ranging from socially conservative Mike Huckabee and Duncan Hunter to more ideologically libertarian voting records of most of the Republican candidates (including Fred Thompson who is running on an image as a social conservative despite having a voting record that was very similar to John McCain).

That none of the candidates are centrally located within the Democratic and Republican may be a major reason why so many Republican office holders have not endorsed a presidential candidate. Elite elected officials rarely endorse a presidential nomination candidate who is ideologically unacceptable, however as we will see, almost any officeholder can find some candidate to be ideologically acceptable. Rather, the problem for Republican officeholders is that none of the candidates are sure bets to appeal to the full range of the Party's various constituencies. Ideologically centrist candidates, within the context of a political party, are not too distant from any segment of the party. However, candidates who deviate from the ideological center may be too moderate for the more ideologically extreme partisans and vice versa. Thus, none of the Republican candidates stands out as a candidate who can easily unify the Republican Party. Since any party's chances of success in the general election depend first and foremost on unifying and mobilizing the mass party membership, nominating a candidate who may not unify the party's constituencies is a recipe for general election disaster. The 2008 Republican candidate field is devoid of a candidate who stands out as an obvious choice as someone who can unify the party. As a result, there is substantial uncertainty about which of the candidates running will appeal to a majority of the party's nominating electorate in the primaries and which can win the general election. Questions about the viability and electability may well be the reasons why the majority of Republican officeholders refrained from making an endorsement prior to the Iowa Caucus. The race is competitive because the candidates all are weak in terms of their ideological appeal to the full range of the Republican Party membership. 
Figure 2. Candidate Endorsements by Congressional Democrats

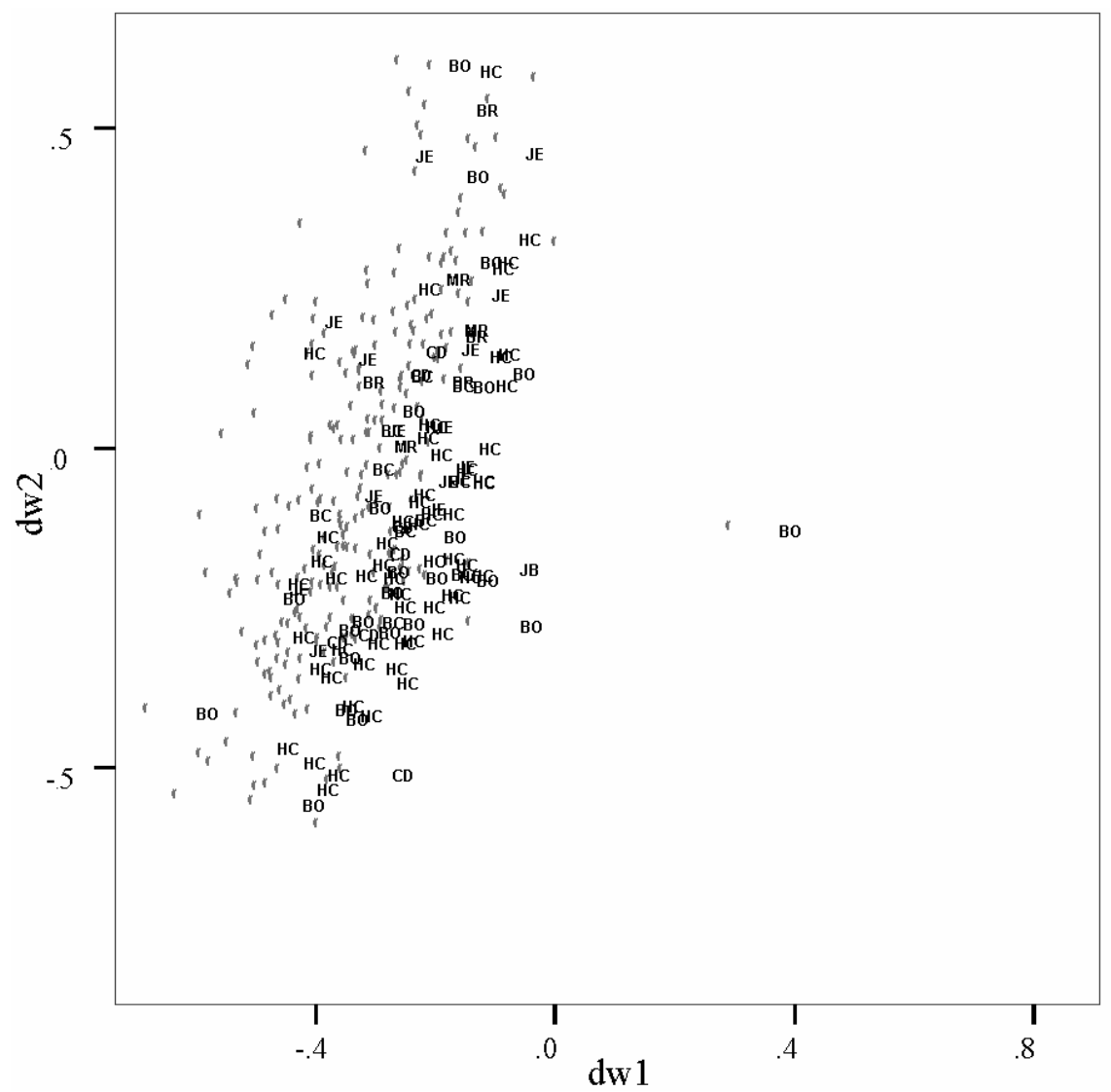

Note: The endorsed candidates' initials are shown for each legislator who has made an endorsement prior to the Iowa caucus.

Knowing who endorses various candidates provides an indication of their appeal among ideological factions of the party. Figure 2 shows candidate endorsements by Democratic members of Congress. The endorsed candidates' initials are shown for each legislator who has made an endorsement prior to the Iowa caucus.

Steger (2007b) found that party elites in both parties generally do not endorse candidates who are ideologically closest to themselves - on either the DW1 or DW2 dimensions. Neither party's federal legislators act in accordance with the assumptions of the median voter theorem with respect to either ideological dimension. Instead, the dominant tendency is for 
legislators to endorse an ideologically centrist candidate. Nomination candidates who are near the ideological extremes of the party rarely receive many endorsements - despite the fact that there are substantial numbers of legislators who are ideologically close to these nomination candidates.

Democratic members of Congress of all ideological stripes have endorsed candidates in the 2008 Democratic nomination; unlike in prior years when more ideologically moderate legislators were less likely to endorse a nomination candidate (Figure 2). Hillary Clinton's endorsements tend to come from more ideologically centrist legislators, but include many endorsements from both moderates and liberals in Congress. Barak Obama has received endorsements from the most liberal and conservative Democrats in Congress, suggesting that he appeals to a slightly wider range of the party with respect to economic issues. Interestingly both Hillary Clinton and Barak Obama received endorsements from the most liberal and conservative Democratic legislators on the DW2 (social) dimension. John Edwards's endorsements tend to come from Southern Democrats in Congress who are more socially conservative.

Figure 3 shows candidate endorsements by Republican members of Congress. The endorsed candidates' initials are shown for each legislator who has made an endorsement prior to the Iowa caucus. The patterns in Figure 3 are similar to those in the Democratic Party but also differ in a number of ways. First, as is usually the case, ideological moderates (on the DW1 dimension) are much less likely to endorse nomination candidates. This pattern is similar to Republicans in prior years, but differs from the Democrats in 2008. Democratic moderates in Congress were about as likely as other legislators to endorse a presidential nomination candidate.

Second, unlike the Democrats, there is no Republican that received endorsements from the full range of ideological positions on the DW2 (social dimension). Mitt Romney, who received the most endorsements among the Republicans running, received endorsements from the widest range of ideological positions, but receives relatively few endorsements from ideologically conservative legislators on the DW1 dimension. John McCain similarly received endorsements more often from economic moderates than conservatives, but does attract support from the full range of Republican legislators on the DW1 (economic dimension). Rudolph Giuliani, who led in national opinion polls, received relatively fewer endorsements (Table 2) but also received endorsements from a much narrower ideological range of the Party's congressional delegation. Despite having a voting record that placed him at the bottom of the DW2 ideological scale, among Republican nomination candidates, former Senator Fred Thompson's endorsements have generally come from more ideologically conservative legislators (with respect to the DW2, social dimension). The 
Figure 3. Candidate Endorsements by Congressional Republicans

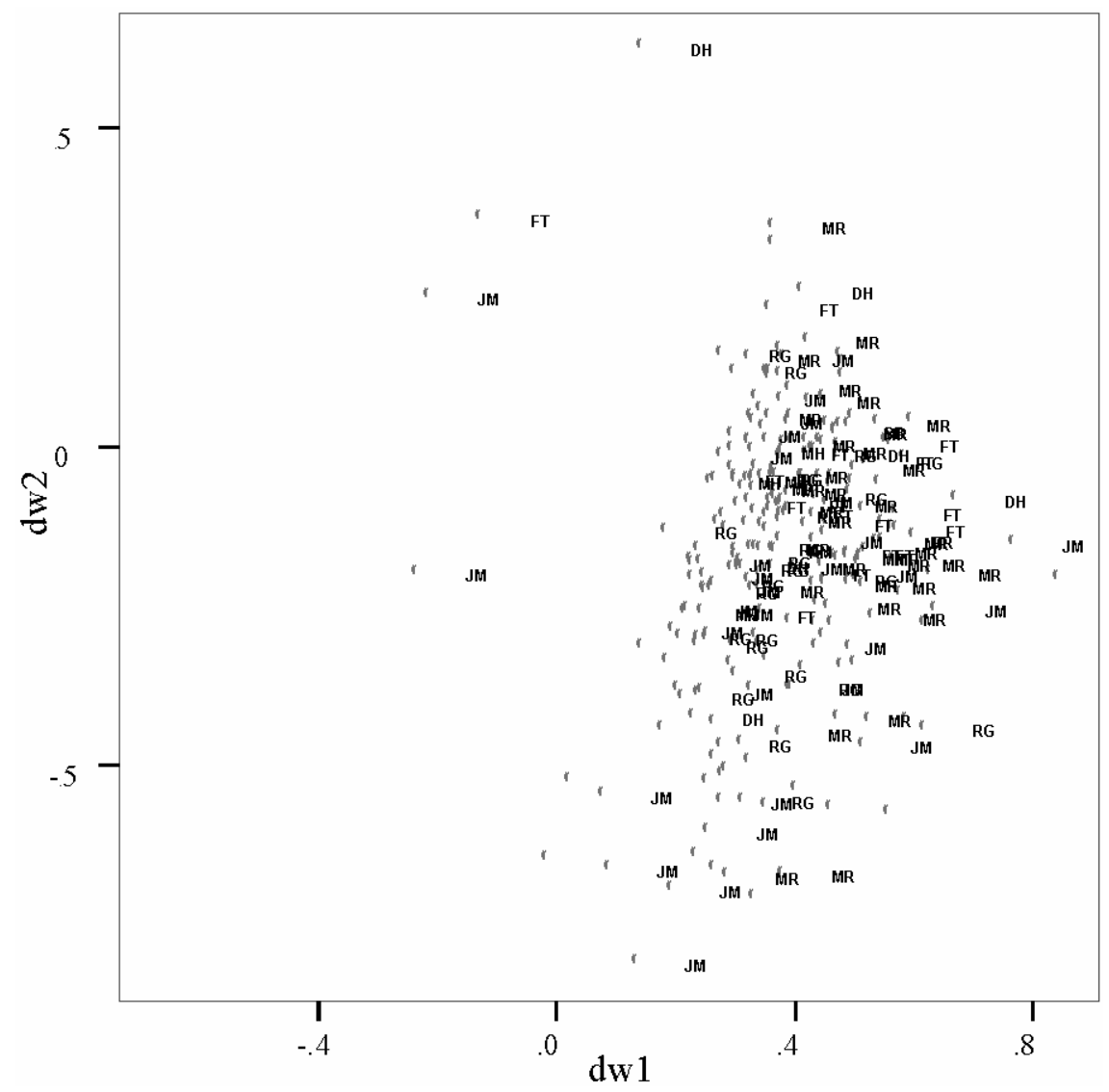

Note: The endorsed candidates' initials are shown for each legislator who has made an endorsement prior to the Iowa caucus.

disjuncture between image and reality is most noticeable for Thompson among all of the candidates running in either political party.

In sum, elite members of Congress appear to be motivated to pick candidates who can win more systematically than they are motivated to pick presidential candidates who are ideologically preferable (Steger 2007b). Legislators from all ideological stripes tend to endorse presidential nomination candidates who are ideologically close to the center of their political party. That seems to be the case again in 2008, though more so for the Democratic Party. The 2008 Democratic presidential nomination candidates are largely ideological centrists within the context of their political party. 
The 2008 Republican candidate field lacks a clearly centrist candidate. Indeed, the candidates closest to the ideological center of the Republican Party-Sam Brownback and Tommy Thompson dropped out of the race well before the Iowa caucus.

\section{Conclusions}

Over the past 30 years, elite Republican office holders have consistently played a more active and influential role in the selection of their party's presidential nominee, compared to Democratic elite officeholders. That pattern does not clearly hold in 2008. Republican officeholders began the campaign as they have in the past, but largely stopped endorsing candidates by late 2007 . Democratic elite officeholders, in contrast, have been somewhat more active in endorsing presidential nomination candidates in 2007.

More so than has been the case in past nomination campaigns, Republican elite officeholders have taken a wait and see approach to making public commitments to their presidential candidates. Unlike prior Republican nominations of the post-reform era, there is not a candidate who stands out as an obvious choice as the most viable and electable candidate in the race. The Republican race has generally lacked a candidate who had a clear lead in public opinion polls or fundraising (a nice barometer of a candidates' appeal among well-heeled political activists within the party). The estimated ideological positions of the candidates suggests that the Republican nomination race is more competitive than past Republican races in part because no candidate in the race is located near the ideological center of the party. None of the Republican presidential candidates appears to be an obvious choice who would appeal - on ideological grounds, to the full range of the Republican Party membership. Whether due to uncertainty or ambivalence about the candidates, Republican elites have been much quieter in signaling which candidates should be nominated. When party elites unify around a candidate they send a clear signal to those attentive to the campaign as to which candidate(s) is/are preferred. When party elites divide among candidates, the informational signal is scattered and attentive publics have less indication as to which candidates are stronger and more preferred.

In contrast to many of the nomination campaigns of the post-reform era, Democratic elite officeholders have been more willing to endorse presidential nomination candidate prior to the 2008 primary season. Both Hillary Clinton and Barak Obama have received notable support among elite officeholders in the Democratic Party. Clinton's has received the support of over half of the Democratic officeholders who made an endorsement prior to the Iowa caucus. In past nominations (for both parties), this threshold has 
indicated a substantial degree of elite coalescence behind a candidate. Such unity in support of a single candidate usually indicates that the candidate is ideologically acceptable, viable, and electable. Cohen et al. (2008a, 2008b) and Steger (2007a, 2008a) argue that party elites are powerful determinants of nomination outcomes when they unify behind a particular candidate. Further, Steger (2008a, 2008b) argues that party insiders' influence on the nomination campaign diminishes as elites divide among the candidates seeking a presidential nomination. If these arguments are correct, then Hillary Clinton should become the Democratic nominee. Since Republican elites failed to unify prior to the primaries, there is no reason to expect that Romney, McCain or Giuliani have any particular advantage going into the caucuses and primaries. The answer to that question should be known by the time this paper is published.

\section{NOTES}

${ }^{1}$ Open nominations are those without an incumbent president seeking renomination. Excluded are renomination races, even if contested, because presidents are difficult to defeat for a variety of reasons (e.g., Steger 2008c). The early favorite is the candidate leading in national Gallup polls two or three years before the election year. For 2008 this is Hillary Clinton for the Democrats and Rudolph Giuliani for the Republicans.

${ }^{2}$ The only early favorite to enter the race and not win was Gary Hart in 1987, who withdrew from the race amid a scandal over an extramarital affair.

${ }^{3}$ The findings of the CKNZ study may differ from those of the Steger studies in part because they analyze different sets of endorsers. Steger uses elite office-holders (presidents, vice presidents, senators, governors, and U.S. representatives, while CKNZ use a broader range of these officials plus state level office holders, unelected party officials, interest groups, and citizen activists. It may be that elite officeholders are relatively more concerned with electability while citizen activists and interest groups are more concerned with policy.

${ }^{4}$ Butler (2004) uses the heir apparent in the same way I refer to the early favorite, but the "heir apparent" need not be the early favorite in national polls. 1994).

${ }^{5}$ Candidate images, once established, are resistant to change (Boynton and Lodge,

${ }^{6}$ I use Bill Richardson's score as a U.S. Representative from the 104th Congress, rather than the average of New Mexico Democrats from the 109th Congress. The differences are small, with a DW1 score of -.321 using the average from the New Mexico Democrats in the 109th Congress and -.255 using Richardson's actual voting score from the 104th Congress. The score for MA Governor Mitt Romney is the average score of MA Republican representatives from the 104th Congress-the most recent Congress for which there were Republicans elected from Massachusetts.

${ }^{7}$ Hart dropped out of the race in April of 1987 amid a marital infidelity scandal. He reentered the race and drew support in national polls, but did not attract many votes in the Iowa caucus and New Hampshire primary.

${ }^{8}$ These data are available at http://voteview.uh.edu/dwnomin.htm. The data are generally stable as the measures are life-time scores updated by recent votes. 


\section{REFERENCES}

Adkins, Randall E., and Andrew J. Dowdle. 2002. The Money Primary: What Influences the Outcome of Presidential Nomination Fundraising? Presidential Studies Quarterly 32:256-275.

Adkins, Randall E., and Andrew J. Dowdle. 2004. Bumps in the Road to the White House: How Influential Were Campaign Resources to Nominating George W. Bush? Journal of Political Marketing 3:1-27.

Bartels, Larry. 1988. Presidential Primaries and the Dynamics of Public Choice. Princeton, NJ: Princeton University Press.

Berggren, D. Jason. 2007. Two Parties, Two Types of Nominees, Two Paths to Winning a Presidential Nomination, 1972-2004. Presidential Studies Quarterly 37:203-227.

Bimber, Bruce, and Richard Davis. 2003. Campaigning Online: the Internet in U.S. Elections. New York, Oxford University Press.

Broder, David S. 1999. Showy Bandwagon is No Free Ride to a Bush Nomination. Washington Post, March 8, p. A1.

Butler, Richard L. 2004. Claiming the Mantle: How Presidential Nominations are Won and Lost Before the Votes are Cast. Boulder, CO: Westview Press.

Ceaser, James W. 1979. Presidential Selection. Princeton, NJ: Princeton University Press.

Cillizza, Chris. 2006. The Friday Line: Winning the 2008 Money Primary. Washington Post, February 3.

Cohen, Marty, David Karol, Hans Noel, and John Zaller. 2003. Polls or Pols: The Real Driving Force Behind Presidential Nominations. Brooking Review 3:36-39.

Cohen, Marty, David Karol, Hans Noel, and John Zaller. 2008a. The Invisible Primary in Presidential Nominations, 1980-2004. Pp. 1-38 in The Making of the Presidential Candidates, ed., William G. Mayer. Roman \& Littlefield.

Cohen, Marty, David Karol, Hans Noel, and John Zaller. 2008b. Political Parties in Rough Weather. The Forum 5(4): article 3.

Dowdle, Andrew J., Randall E. Adkins, and Wayne P. Steger. 2008. The Viability Primary: Modeling Candidate Support Before the Primaries. Political Research Quarterly, forthcoming.

Embrey, George. 1995. Davidson, Aronoff Back Dole; Endorsements Boost Senator's Presidential Bid in Ohio. Columbus Dispatch, March 17, p. 8A.

Garramone, Gina. 1985. Effects of Negative Political Advertising: the Roles of Sponsor and Rebuttal. Journal of Broadcasting and Electronic Media 29:147-159.

Geer, John G. 1989. Nominating Presidents, An Evaluation of Voters and Primaries. New York: Greenwood Press.

Gimpel, James G. 1998. Packing Heat at the Polls: Gun Ownership, Interest Group Endorsements, and Voting Behavior in Gubernatorial Elections. Social Science Quarterly 79:634-648.

Gopoian, J. David. 1982. Issue Preferences and Candidate Choice in Presidential Primaries. American Journal of Political Science 26:523-546.

Herrera, Richard. 1995. The crosswinds of change: sources of change in Democratic and Republican parties. Political Research Quarterly 48:291-312.

Keeter, Scott, and Cliff Zukin. 1983. Uninformed Choice: the Failure of the New Presidential Nomination System. New York: Praeger. 
Kenney, Patrick J. 1993. An Examination of How Voters Form Impressions of Candidates' Issue Positions During the Nomination Campaign. Political Behavior 315: 265-288.

Kirkpatrick, Jeanne J. 1976. The New Presidential Elite. New York: Russell Sage Foundation.

Jamieson, Kathleen Hall, Richard Johnston, and Michael G. Hagen. 2000. The 2000 Nominating Campaign: Endorsements, Attacks, and Debates. Research Report. Annenberg Public Policy Center. University of Pennsylvania.

Mayer, William G. 1996a. Forecasting Presidential Elections. Pp. 44-71 in In Pursuit of the White House, ed. William G. Mayer. Chatham, NJ: Chatham House.

Mayer, William G. 1996b. The Divided Democrats: Ideological Unity, Party Reform, and Presidential Elections. Boulder, CO: Westview.

Merrion, Paul. 1995. Local elected official Money Machine Gets Cranking for Bob Dole. Crain's Chicago Business, May 1, p. 3.

Norrander, Barbara. 2000. The End Game in Post-Reform Presidential Nominations. Journal of Politics 62:999-1013.

Novak, Robert. 2006. Is GOP '08 Choice Already Written in Inc.? Chicago Sun Times, December 14, p. 43.

Petrocik, John R. 1995. Issue Ownership in Presidential Elections, with a 1980 Case Study. American Journal of Political Science 40:825-850.

Polsby, Nelson W. 1983. Consequences of Party Reform. New York: Oxford University Press.

Poole, Keith T., and Howard Rosenthal. 1997. Congress: A Political-Economic History of Roll Call Voting. New York: Oxford University Press.

Poole, Keith T., and Howard Rosenthal. 2001. D-NOMINATE After 10 Years: An Update to Congress: A Political-Economic History of Roll Call Voting. Legislative Studies Quarterly 26:5-29.

Poole, Keith T., Howard Rosenthal, and Nolan McCarty. 1997. Income Redistribution and the Realignment of American Politics. Washington DC: AEI Press.

Ranney, Austin 1975. Curing the Mischiefs of Faction: Party Reform in America. Berkeley: University of California Press.

Reiter, Howard L. 1985. Selecting the president: the nominating process in transition. Philadelphia: University of Pennsylvania Press.

Shaw, Daron R., and Bartholomew H. Sparrow. 1999. From the Inner Ring Out: News Congruence, Cue-taking and Campaign Coverage. Political Research Quarterly 52:323-351.

Steger, Wayne P. 2007a. Who Wins Nominations and Why? An Updated Forecast of the Presidential Primary Vote, Political Research Quarterly 60:91-99.

Steger, Wayne P. 2007b. Ideological information in candidate endorsements for presidential nominations. Paper presented at the annual meeting of the American Political Science Association, Chicago.

Steger, Wayne P. 2008a. Inter-Party Differences in Elite Support for Presidential Nomination Candidates. American Politics Research, forthcoming.

Steger, Wayne P. 2008b. Candidate Endorsements in Presidential Nomination Campaigns. In Voting in America, ed. Morgan Felchner. Westport, CT: Greenwood Press, forthcoming.

Steger, Wayne P. 2008c. Forecasting the Presidential Primary Vote: Multiple Candidates in Sequential Elections. International Journal of Forecasting, forthcoming. 


\section{8 | Wayne P. Steger}

Steger, Wayne P., Andrew J. Dowdle, and Randall E. Adkins. 2004. Partisan Differences in the Exhibition Season and New Hampshire Primary. Political Research Quarterly 57:375-390.

Williams, Christine B., Ellen R. Foxman, and Jeff Gulati. 2008. What's in an Endorsement? An Analysis of Endorsement Use on the Websites of Presidential Candidates and Organizations in 2004. Journal of Political Marketing, forthcoming.

Zaller, John R. 1992. The Nature and Origins of Mass Opinion. Cambridge, NY: Cambridge University Press. 